\title{
Graduation Profiles of Pedagogy Programmes According to the Current Educational Policies
}

\author{
Jessica C. Medina ${ }^{1} \&$ José A. González ${ }^{2}$ \\ ${ }^{1}$ Pontificia Universidad Católica de Valparaíso, Chile \\ ${ }^{2}$ Universidad de Playa Ancha, Chile \\ Correspondence: Jessica C. Medina, Pontificia Universidad Católica de Valparaíso, Chile.
}

\author{
Received: December 17, $2018 \quad$ Accepted: January 18, $2019 \quad$ Online Published: May 29, 2019 \\ doi:10.5539/ies.v12n6p83 \\ URL: https://doi.org/10.5539/ies.v12n6p83
}

\begin{abstract}
The research analyzes the graduate profiles of pedagogical careers belonging to the universities of the Valparaíso region, Chile. For this purpose, a metrically consistent instrument has been proposed and created, according to the main Education Policies of the country that is called as an integral profile, which includes aspects with which Chilean teachers are evaluated, plus indicators of inclusion and citizen education. These Policies are not always measured, that's why universities give such importance to these three educational policies. For these reasons, the objective of this article is to analyze, based on quantitative techniques, the relation of similarity between graduation profiles and educational policies, contributing to empower the descended aspects and to visualize the importance that the universities grant to train students with an integral profile. The results of this research invite to promote the Educational Policies related to the exit profiles of the pedagogical careers, since having integral profiles contributes to form a model of teacher training for the country, especially in those with emerging economies, such as those of Latin America.
\end{abstract}

Keywords: accreditation, integral profile, initial teacher training, measurement of profiles

\section{Introduction and Background to the Research Problem}

The last years the quality of education has been part of Public Policies at all levels and initial teacher training has not been the exception, since the footprint of these careers, quality, has a greater impact on the formation of people from the first formal education (Schwartzman, 2015). In this way, teachers are considered a key element to improve education in the country (Darling-Hammond, 2010). For this reason, the Higher Education Guarantee Law was published and promulgated in Chile (2006), thus strengthening initial teacher training, which established compulsory accreditation of pedagogical careers (of all universities ) and a system that should ensure the quality of teachers who will begin their professional careers (Ministry of Education, 2006). The accreditation is in charge of the National Accreditation Commission (CNA), a public and autonomous body that takes care of the quality of the institutions and the undergraduate and postgraduate careers. The CNA established different requirements or standards that have allowed to ensure quality, one of them is: the exit profile.

\subsection{Professional Profile}

At present, the professional profile, specifically the teaching profile, is understood as the set of skills and competencies that characterize the formation of students composed of basic, specific and transversal skills (Quintanal, García \& Martínez, 2007). Currently, teaching profiles must be more than a list of competences, but must contain cognitive, attitudinal, evaluative and skill elements such as: problem solving and technological evolution (Galvis, 2007). Given the variety of requirements that current graduation profiles must possess, the CNA states that they must consider the disciplinary foundations and guidelines that reflect the mission, vision and institutional purposes, a disciplinary update consistent with the current Policies, among others (Ministry of Education, 2006).

Considering the importance of the exit profiles and according to the requirements, it is necessary to have an instrument that allows to measure what they declare and how coherent they are with the current Educational Policies. The instrument with which the exit profiles of the pedagogical careers of the region of Valparaíso, Chile will be analyzed, will be a checklist and will be based on the main teaching competences, which at the same time represent the main educational policies of the country: Teaching professional development system, Citizen 
Training and Inclusion. One of the benefits of including a variety of skills in initial training is to create and strengthen a professional identity, helping to form a model of teachers for the country (Atmaca, 2017).

\subsection{Teacher Professional Development System}

The Teacher Professional Development System is based on standards, known as the Framework for Good Teaching. It was proposed in 2008 by the Ministry of Education. The Framework refers to the work of the teacher and the standards of teacher evaluation, whose structure was divided into four domains: Preparation of teaching (Domain A), Creating an enabling environment for learning (Domain B), Teaching for the learning of all students (Domain C) and Professional Responsibilities (Domain D) (Ministry of Education, 2008). Therefore, the indicators of the instrument will be based on the aforementioned Domains, given its importance both for initial training and for the teaching profession.

\subsection{School Inclusion Law}

According to the relevance of attitudes in society and especially in education, from a formative and integrative perspective, the School Inclusion Law was enacted in Chile in 2015. The Ministry of Education creates the law born to regulate the admission of students, eliminate shared financing and prohibit profit in educational establishments. However, elements that refer to eliminate all forms of discrimination in educational establishments are added and these must be transformed into a meeting place for students of different socio-economic, cultural, ethnic, gender, nationality or religion conditions (Ministry of Education, 2015). Although this area is currently not evaluated, it should be considered in any process of initial teacher training, especially in a possible restructuring of the pedagogical practices (Canelo, 2016). The teaching of social and emotional education in schools is an urgent need and must be taught by teachers who are highly trained in these aspects (Weare, 2011).

From the point of view of attitudes, schools must grow under values of respect for difference and commitment where all students have access to learning opportunities (Alegre \& Villar, 2015). Commenting on this, Rajovic and Jovanovic (2013) concluded, according to a study in Serbia, that teaching attitudes towards inclusion were deficient, since initial training was deficient, so they suggested that the formation of attitudes should be a continuous process throughout the professional career, but strengthened in the initial teacher training. The above is reaffirmed in a study by Sharma and Nuttall (2016) revealing that teachers in training without previous experience in subjects such as disability showed high levels of concern and less effectiveness in practice, while those who were trained and prepared were more effective in the practice and lower levels of concern. Thus, research promotes teaching and learning attitudes of diversity and inclusion in initial teacher training, since when addressing the strengthening of these issues (inclusion, commitment and understanding of discriminatory relationships) and at this stage, develops better teachers (Sharma \& Nuttall, 2016). Therefore, it is necessary to incorporate fundamental aspects in education such as: diversity and inclusion, avoid classifications and understand the basis of discrimination.

Additionally, the latest studies have strengthened other aspects of inclusion, such as the Universal Learning Design, which was created for architecture, but has now been implemented in education, helping to understand and adding contributions. to the work that the teacher does in the classroom, with its principles of providing multiple means of: representation, expression and commitment (Wakefield, 2008). For the construction of the inclusion indicators, only the first principle, understood in education, will be taken as the different ways of presenting the topics or contents to the students and with this, enhancing a diversity of skills.

According to the evidence indicated above, it is necessary to add inclusion indicators, which must be present in the initial training, therefore in the exit profiles. As there are already four domains (in the MBE), we will call Domain E the inclusion indicators.

\subsection{The Citizenship Training Plan}

On the other hand, the Citizenship Training Plan promulgated in 2016 by the Ministry of Education, establishes that establishments must include a Plan that integrates and complements the curriculum in the Preschool, Primary and Secondary Education levels, in this way it is intended to achieve students socially responsible, that have an orientation toward the integral improvement of the human person sustained in the democratic system, social justice, progress and knowledge in the political and economic organization of the country. Citizen education should be based on values, with a vision of a world centered on the human being and the natural and social environment promoted from the initial teacher training (Minsiterio de Educación, 2016). As with inclusion, citizenship education is not evaluated in initial training or in teaching practice, despite being an essential educational policy for current society and the one that is to be built (Canelo, 2016).

Day (2005) points out that identity is related to the sense of belonging, that is why we lose it when we forget 
relevant information, such as our history, local identity, among others. In this way, personal, professional, intellectual, social and emotional identity are fundamental aspects for the construction of society and should be strengthened throughout education. Luke (1998) says in a study for the reform in the State of Queensland (Australia), focused on the idiosyncrasy of the local to strengthen the curriculum mixed with particular approaches of the educational establishments themselves. Thus, each school built its own path considering its identity, first placing emphasis on the teaching of higher risk students with inclusion practices and then focusing on a local and individual vision of each group (Luke, 1998). Given the above, it is necessary to establish an indicator that mentions the importance of the local and / or national identity.

A study by Aspeé, González, and Cavieres-Fernández (2018) indicates that the students who have more preparation in personal-integral and citizen formation, as studies of the political and democratic system of the country help to develop a critical thought and present a complex commitment, understood as a complex phenomenon, not static, product of the actions of students. Likewise, promoting student commitment could result in the commitment that students will have later, such as in higher education. For this reason, the commitment must be measured in the initial formation. Finally, to develop citizenship, a teacher must have tools such as: knowledge and mediator of culture, guarantor of the law and have a high commitment to the institutions to which it belongs (Galvis, 2007).

Given the relevance of citizen education as an Educational Policy, it is necessary to add indicators in the graduate profiles of pedagogical careers. For this reason, we will call Domain F the indicators of citizen education.

Due to the above and according to the importance of the three mentioned Educational Policies, it is necessary that the instrument for measuring the exit profiles of initial teacher training, consider integral aspects that reflect the training of a professional capable of working according to the current demands. For this, the criteria present in the Framework for Good Teaching (with its four domains), relevant aspects of the Inclusion Law and the requirements of the Citizen Training Plan are considered. The foregoing will be referred to as "integral profile".

In order to solve these problems, the objectives of this study include: to analyze the graduation profiles of Pedagogy careers in the Valparaíso region, in accordance with the current Educational Policies. To achieve this objective, 4 specific objectives are set: 1) hierarchize higher education institutions and careers in pedagogy based on the scores obtained with respect to the overall profile, 2) describe the homogeneity of the domains of the universities in the region and careers within the same university, 3) determine the level of dependence of the results obtained with the years of accreditation and 4) determine and prioritize the commitment assumed by the universities in the region with the achievement of Domains E and F.

This work helps to guide, focus and strengthen Educational Policies, both regionally and nationally, since strengthening initial teacher training contributes to improving the quality of education, especially in countries with emerging economies.

\section{Research Method}

This article is to analyze, based on quantitative techniques, the relation of similarity between graduation profiles and educational policies.

\subsection{Research Questions and Hypotheses}

From the formal perspective, the hypothesis of research is an almost exclusive attribute of inferential studies, due to the fulfillment of some distributional assumptions, however, in this investigation some hypotheses have been proposed so that the decisions based on the evidence provided for the data serve as guiding assumptions of future research, deciding in percentage terms or relative increases.

Table 1. Research questions and hypothesis

\begin{tabular}{|c|c|}
\hline Questions & Hypotheses \\
\hline $\begin{array}{l}\text { Do the new Domains have a lower percentage of achievement } \\
\text { compared to the other Domains? }\end{array}$ & $\begin{array}{l}\text { Hypothesis 1: Domains } \mathrm{E} \text { and } \mathrm{F} \text { have a lower percentage of } \\
\text { achievement with respect to Domains } \mathrm{A}, \mathrm{B}, \mathrm{C} \text { and } \mathrm{D} \text {. }\end{array}$ \\
\hline Does Domain A achieve the highest percentage of achievement? & $\begin{array}{l}\text { Hypothesis 2: Domain A has a higher percentage of achievement with } \\
\text { respect to the rest of the Domains. }\end{array}$ \\
\hline $\begin{array}{l}\text { Is the achievement percentage of the integral profile directly } \\
\text { dependent on the years of accreditation of the careers? }\end{array}$ & $\begin{array}{l}\text { Hypothesis } 3 \text { : There is a direct dependence between the achievement } \\
\text { of the integral profile and the years of accreditation. }\end{array}$ \\
\hline
\end{tabular}




\subsection{Data Collection Instrument}

To collect the data, a checklist or verification list was created as an abstraction instrument, which has been called an integral profile. Its construction is based on indicators, which have been classified in Domains (A, B, C, D, E and $\mathrm{F}$ ). Through observation, the presence or absence of the indicators in the graduation profiles is determined. In order to ensure the metric quality of the registration process, the survey was replicated three times, obtaining a factor of similarity in the records above 95\% (Cairns, Santoyo, Fergunson, \& Cairns, 1991).

\subsection{Population and Sample}

All pedagogical careers in the Valparaíso region have been considered as the study population, which in turn correspond to the 6 universities that teach them. The universities have different characteristics: state, private, members of the CRUCH (Council of Rectors of the Chilean Universities). These will be named as: University No. 1: U1; University No. 2: U2; University No. 3: U3; University No. 4: U4; University No. 5: U5; University No. 6: U6.

\subsection{Calibration of the Instrument}

In this section the processes of compliance with the metric characteristics of an instrument are described, referring to reliability and validity.

To build and validate the checklist, the four-step validation model of Escobar and Cuervo (2008) was followed:

\subsubsection{1st Stage - Bibliographic Search}

The source of information that has been used is the scientific literature on the requirements for the construction of graduation profiles, the main Educational Policies of the country and the international experience of profile evaluation in these subjects.

\subsubsection{2nd Stage - Reliability of the Instrument}

For the reliability analysis (to instrument), as an indicator of internal consistency, the Cronbach's Alpha coefficient was used as an estimator, whose estimates were 0.8448 and standardized 0.8355 . Concluding a high quality in internal consistency of the instrument.

\subsubsection{3rd Stage - Validity of the Instrument}

For the quantification of the estimation of validity, the coefficient $\Gamma$ was used (González, Carvajal \& Viveros, 2016), obtaining 0.8453 , implying high validity. In this way, it is concluded that the instrument has the desirable metric characteristics to support the conclusions. Additionally, the indicators were supported by experts with teaching experience, extensive knowledge in Educational Policies and experts in quantitative techniques. Validation was organized in the criteria of sufficiency, clarity, coherence and relevance (Escobar \& Cuervo, 2008).

\subsection{Data Analysis}

For the statistical analysis of the data, R-Project was used, particularly the Rcmdr package, which is freeware and compatible with frequently used databases. The databases were prepared in Excel, and revised in coding with $\mathrm{R}$, thus reducing the presence of missing data or non-identification of variables.

\section{Results}

In this section, the results are presented in coherence with the objectives and research questions stated earlier. It must be indicated that the results are based on the scores obtained in the elaborated instrument, which is made up of 28 indicators, whose punctuation form is dichotomous, that is, it has or does not have the indicator, and the total score in the instrument is of 28 points, identified as an integral profile $100 \%$ achievement or closest to it, which is presented in the annex. 


\subsection{Analysis No. 1: Hierarchy of Universities}

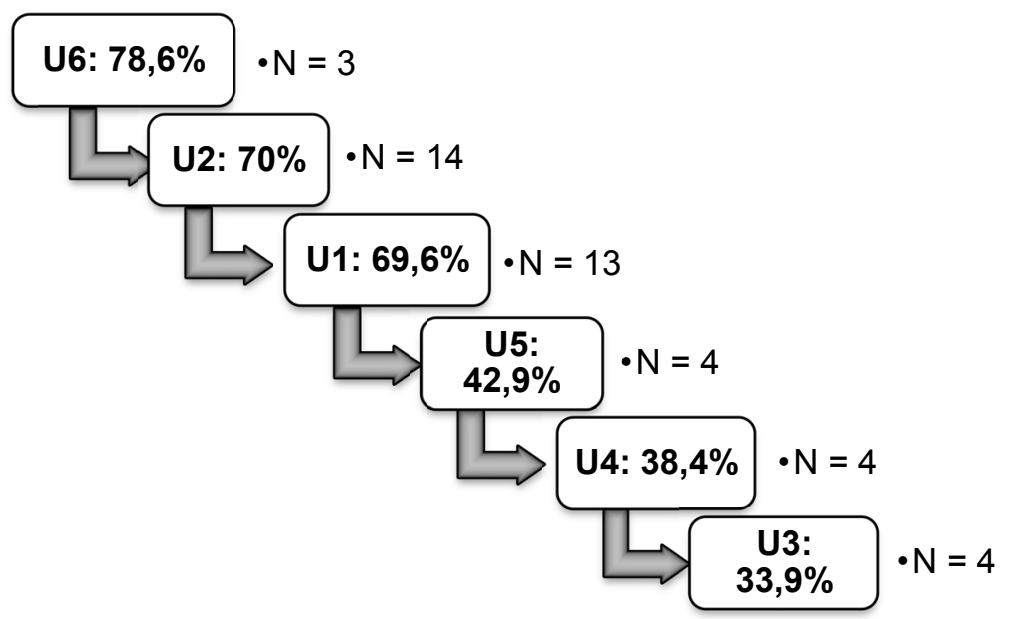

Figure 1. Hierarchy of the universities in the region

As can be seen in the figure in Figure 1, U6 has remained in the first hierarchical position with 78.6\% achievement and in contrast U3 with $33.9 \%$ achievement, establishing a percentage difference of approximately $45 \%$ in achievement of the integral profile among higher education institutions in the same region. On the other hand, it becomes evident the number of pedagogical careers that identify each university, represented in the graph with the letter $\mathrm{N}$. The intention to visualize $\mathrm{N}$ is to understand that the percentage of achievement is not related to the number of pedagogical careers that the university in question owns. However, it is important to highlight the high percentages of achievement of institutions with greater pedagogical careers.

\subsection{Analysis No. 2: Hierarchy of Careers}

Table 2. Hierarchy of the region's careers

\begin{tabular}{cccc}
\hline Place & Careers & Percentage of achievement & $\mathrm{N}^{\circ}$ careers \\
\hline $1^{\circ}$ & Chemistry Pedagogy & $76.8 \%$ & 2 \\
$2^{\circ}$ & Special Education Pedagogy & $72.5 \%$ & 3 \\
$3^{\circ}$ & Spanish Pedagogy & $69.6 \%$ & 2 \\
$4^{\circ}$ & Arts Pedagogy & $67.8 \%$ & 1 \\
$5^{\circ}$ & Biology Teaching & $66 \%$ & 2 \\
$6^{\circ}$ & Physics Pedagogy & $62.5 \%$ & 2 \\
$7^{\circ}$ & Nursery Teaching Education & $61.8 \%$ & 6 \\
$8^{\circ}$ & History Teaching & $61.8 \%$ & 3 \\
$9^{\circ}$ & Pedagogy in Mathematics & $60.7 \%$ & 2 \\
$10^{\circ}$ & Pedagogía in Philosophy & $59.2 \%$ & 3 \\
$11^{\circ}$ & English Pedagogy & $58.9 \%$ & 4 \\
$12^{\circ}$ & Primary Teaching & $57.1 \%$ & 5 \\
$13^{\circ}$ & Music Pedagogy & $56.3 \%$ & 3 \\
\hline
\end{tabular}

According to the analysis carried out, the race within the region that achieves the highest percentage of achievement with respect to the integral profile is Pedagogy in Chemistry with a $76.8 \%$ achievement, while the career that achieves the most descending achievement is Pedagogy in Physical Education with a 52.3\% achievement with respect to the integral profile, marking a difference between these two races of more than $24 \%$ achievement.

It is important to mention that the number of careers $(\mathrm{N})$ varies between 1 , only given by a university as Pedagogy in Plastic Arts, and 6, given by all universities as Nursery Education. The average number of careers 
found in the region of each pedagogy is 3 .

\subsection{Analysis No. 3: Homogeneity of the Domains}

Table 3. Homogeneity of domains and universities

\begin{tabular}{ccccccc}
\hline & Domain A & Domain B & Domain C & Domain D & Domain E & Domain F \\
\hline U1 & 15.52 & 20.80 & 24.96 & 21.00 & 23.68 & 28.16 \\
U2 & 8.51 & 11.86 & 10.26 & 19.88 & 6.68 & 15.39 \\
U3 & 25.16 & 23.93 & 8.33 & 30.0 & 14.43 & 20.41 \\
U4 & 19.14 & 12.50 & 23.57 & 28.28 & 25.0 & 31.45 \\
U5 & 0 & 0 & 8.33 & 20.0 & 14.43 & 12.5 \\
U6 & 0 & 0 & 0 & 0 & 0 & 0 \\
\hline
\end{tabular}

The results of Table 3 correspond to the standard deviation presented by the careers of each university for each of the Domains. Here it is possible to observe that the U6 presents the most homogeneous results in their careers with respect to the other universities, followed by the U5 that has two Domains, A and B, which obtain the same score and by the $\mathrm{U} 2$ that presents a lower standard deviation in the achievement of their careers.

\subsection{Analysis No. 4: Level of Dependence and Years of Accreditation}

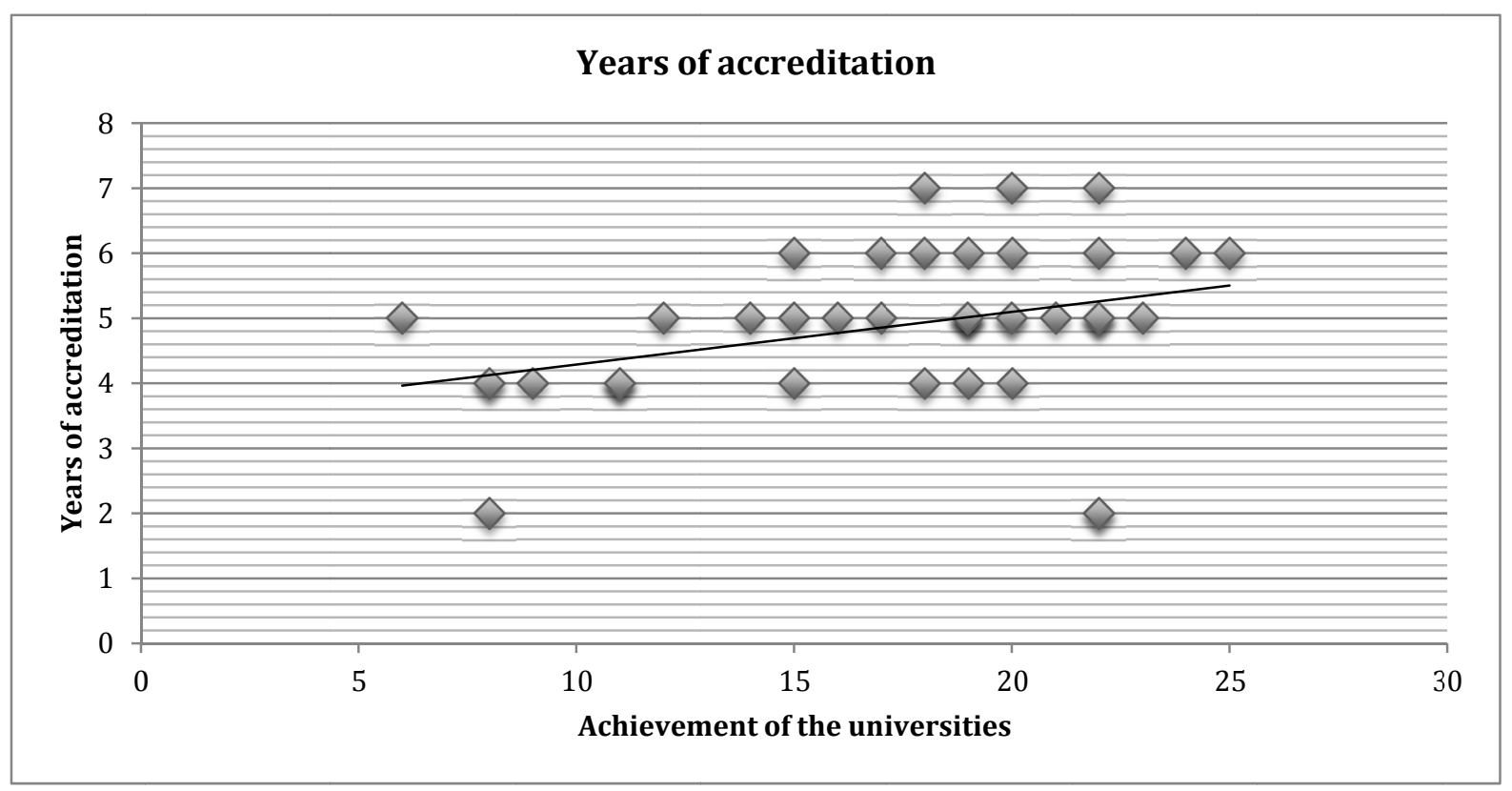

Figure 2. Relation between the achievement of the universities with the years of accreditation

The total graduation profiles of the pedagogical careers analyzed was 42. Figure 2 shows the relationship of the integral profile score and the years of accreditation of 41 careers. One of the races is in a new accreditation process, which is why its years are not yet available.

The total score of the integral profile corresponds to 28 points, of this total the race that obtains the highest score is 25 points with 6 years of accreditation. However, a career has only 6 points with 5 years of accreditation. Other careers, instead have 7 years of accreditation, the maximum granted by the CNA, and get 18 points, while there are careers that obtain 2 years of accreditation, the minimum granted by the CNA, and the score that they reach of the integral profile is of 8 and 22 points.

Due to the above, it is possible to affirm that the integral profile score is independent of the years of accreditation of the careers. On the other hand, from the objective perspective, an association study was performed between 
the variables, quantified through Pearson's linear correlation coefficient, obtaining the value of 0.3316 , which in percentage terms, according to the coefficient of determination, concludes that the $11 \%$ of the variability of the years of accreditation are explained by the score in the instrument, situation that is visualized in Graph 2 . Likewise, a recent study by González, Sarzoza, and López (2018), affirm similar results, since they showed that there was no correspondence between the results of the evaluation criteria and the accreditation time granted to the doctoral programs, being consistent in part with the results obtained in this study.

\subsection{Analysis No. 5: Achievement of Domains $E$ and $F$}

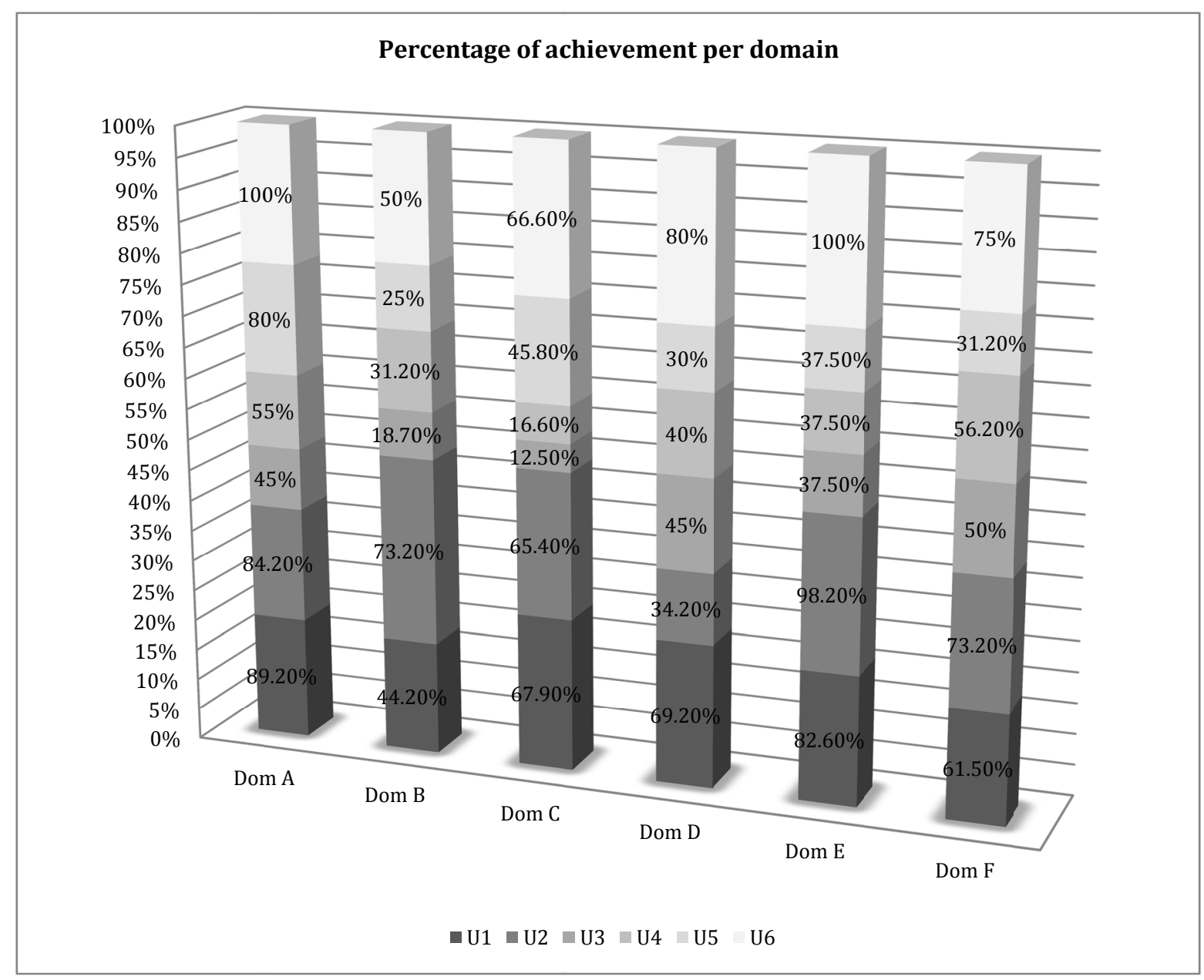

Figure 3. Average of achievement of the dominions by University 


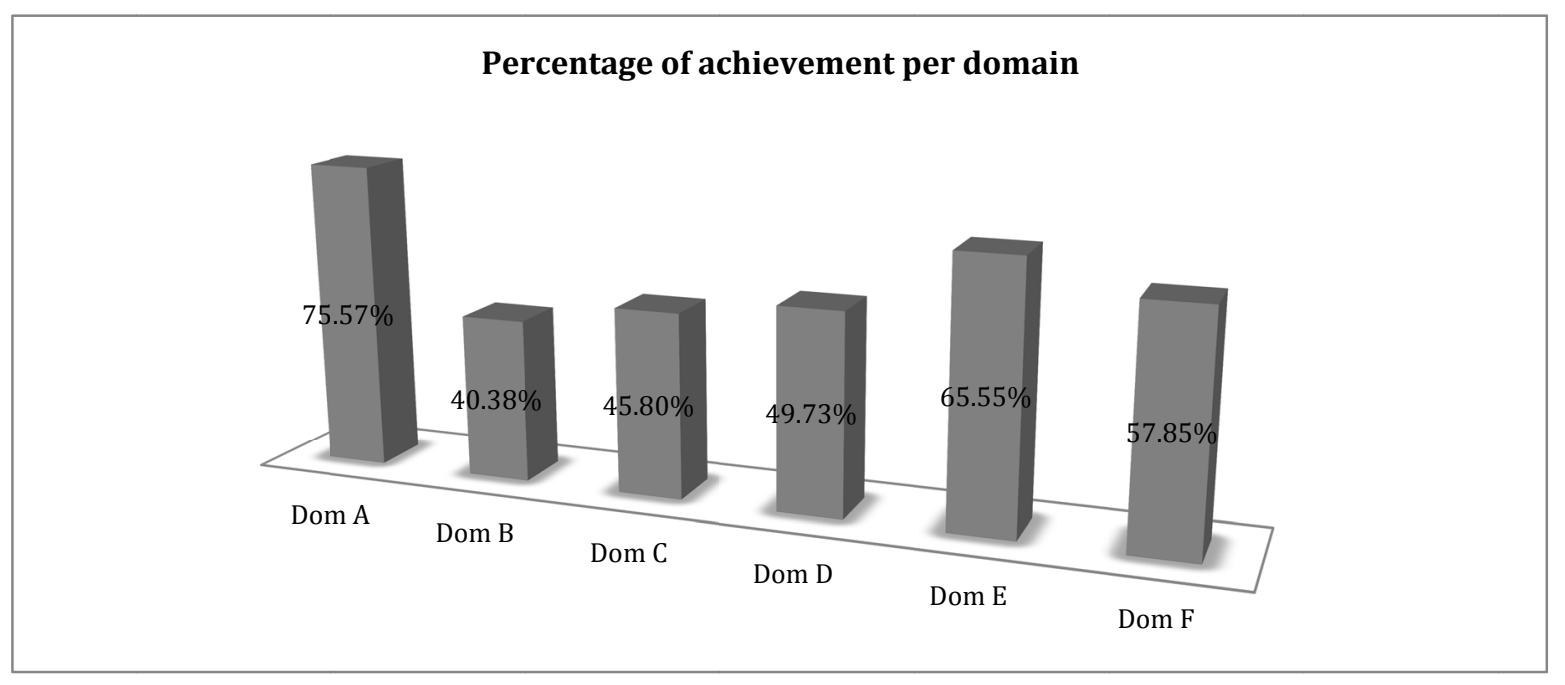

Figure 4. Average achievement of the domains

In Figure 3 and 4 it is possible to observe a high achievement achieved in Domain A, followed by E, F, D, C and B. Domains A, B, C and D are indicators of the evaluation of teachers in practice, so they are understood to have a high percentage of achievement, while Domains $\mathrm{E}$ and $\mathrm{F}$ are not evaluated, however they obtain a high percentage of achievement, remaining in the 2 nd and 3 rd place. This means that the universities recognize the importance of these two Educational Policies and visualize an effort for their acquisition and fulfillment.

\subsection{Analysis No. 6: Testing Hypotheses}

Although the following study is not inferential, hypotheses have been proposed to strengthen research. The results obtained were the following: Hypothesis 1 - Domains $E$ and $F$ have a lower percentage of achievement with respect to Domains $A, B, C$ and $D$ : As shown in figure 4, Domains $\mathrm{E}$ and F occupy the 2nd and 3rd place of achievement with respect to the other domains, being overcome only by domain A. Based on this result, the researcher will reject Hypothesis 1.

Hypothesis 2 - Domain A has a higher percentage of achievement compared to the rest of the Domains: Domain A ranks 1st, that is, the highest percentage of achievement (Figure 4). Therefore, the researchers, will fail to accept hypothesis 2 .

Hypothesis 3 - There is a direct dependence between the achievement of the integral profile and the years of accreditation: As can be seen in Figure 2, the percentage of achievement of the integral profile reached by the pedagogical careers is independent of the years of accreditation. Based on this result, the researcher will reject Hypothesis 3.

\section{Discussion}

Domain A is the most achieved by all universities, however there are more descended Domains such as B, C and $\mathrm{D}$ that do not reach 50\% achievement. Therefore, it is important that universities, through Educational Policies, focus their efforts on achieving an integral profile, that is, professionals capable of working in the current work context, especially when dealing with quality of education, inclusion and citizen education (Atmaca, 2017).

Different studies indicate that there a distancing between what is taught in the university and the skills that one has at job, evidencing the lack of articulation between theory and practice (Pereira, Da Silva, Gonçalves y Rosa, 2018). Therefore, it is necessary to generate indicators for the teaching work. These indicators should serve as connectors between the educational world and the working world (Schön, 1992).

This research would be a contribution to the problem mentioned above.

\section{Conclusions and Recommendations}

The initial teacher training is a fundamental part to improve the quality of education, more when they are accompanied and aligned with the requirements and Educational Policies that are currently necessary.

Given the importance of the aforementioned, this study detected the main strengths and weaknesses of the graduate profiles of the pedagogical careers declared by the universities of the Valparaíso region, Chile. 
It is important to mention that universities in the region have focused on delivering disciplined training in their graduates, which is seen in the high percentage of achievement of Domain A and at the same time make efforts and have contemplated Domains E and F, for the percentage of achievement that reach $65.55 \%$ and $57.85 \%$ respectively, however it is important to continue focusing efforts to promote the transcendental Policies such as Inclusion and Citizen Training, especially in indicators such as: Mention aspects of the political organization of Chile, the one that is only declared by 6 races of the region, since this indicator is related to forming socially responsible, integral people with a knowledge of the democratic system.

Another finding of this research is that the careers and universities that come closest to an integral profile, do not necessarily get more years of accreditation. Therefore, there is no dependence between the variables: percentage of achievement and years of accreditation.

Other countries and states have already made similar efforts, as in the case of South Africa, where they have worked and implemented Educational Policies such as the Suoth African School Act and the NNSSF policy, which focus on social justice and equity, not without problems in its implementation, but continue to place their efforts on these very relevant policies (Mestry \& Ndhlovu, 2014). Thus, train integral teachers: with cognitive skills, attitudes and commitment to society, contributes to improving the quality of education and thus to obtain a better quality of life.

Having integral profiles, would provide:

- $\quad$ a teacher's model for the country;

- $\quad$ professors with diverse competences (cognitive and transversal);

- transversal teaching for students.

For the above reasons, Chile should focus its efforts on promoting Education Policies, monitoring and evaluating them to determine their achievements and impacts that they have on education and especially on society. It would be expected that countries in Africa and Latin America continue to strengthen the profiles of graduates, through their Educational Policies.

\section{References}

Alegre, O., \& Villar, L. (2015). Inclusión e interculturalidad. Un estudio en el marco de la enseñanza universitaria. Revista nacional e internacional de educación inclusiva, 8(3), 12-29.

Aspeé, J., González, J., \& Cavieres-Fernández, E. (2018). El compromiso estudiantil en educación superior como agencia compleja. Formación Universitaria, 11(4), 95-108. https://doi.org/10.4067/S0718-50062018000400095.

Atmaca, C. (2017). English teachers' perspectives about teacher competencies in terms of professional identity. Abant İzet Baysal Üniversitesi Eğitim Fakültesi Dergisi, 17(4), 1641-1669. https://doi.org/10.17240/aibuefd.2017.17.32772-363955

Cairns, R., Santoyo, V., Fergunson, L., \& Cairns, B. (1991). Integración de información interaccional y contextual: El procedimiento de las observaciones sincrónicas. Revista Mexinaca de Análisis de la conducta, $17(3), 105-120$

Canelo, P. (2016). Innovación Curricular: Universidad de Playa Ancha (1st ed.). Valparaíso, Chile: UPLA.

Day, C. (2005). Formar docentes. Madrid, España: Narcea S.A. de Ediciones.

Darling-Hammond, L. (2010). Teacher Education and the American Future. Journal of Teacher Education, 61(1-2), 35-47. https://doi.org/10.1177/0022487109348024

Escobar, J., \& Cuervo, Á. (2008). Validez de contenido y juicio de experto: una aproximación a su utilización. Avances en Medición, 6, 27-36.

Galvis, R. V. (2007). De un perfil docente tradicional a un perfil docente basado en competencias. Acción Pedagógica, 16, 48-57.

González, J., Carvajal, C., \& Viveros, F. (2016). Coeficientes edumétricos para la validez y dificultad de un test: Propuesta. Estudios Pedagógicos, 42(3), 467-481. https://doi.org/10.4067/s0718-07052016000400025

González, J., Sarzoza, S., \& López, D. (2018). Aproximación metodológica a la metaevaluación de programas doctorales. Revista Venezolana de Gerencia, 23(1), 278-294.

Jeisson, M. (2018). Calidad educativa en la educación superior colombiana: una aproximación teórica. Sophia-Education, 14(2), 1-11. https://doi.org/10.18634/sophiaj.14v.2i.799 
Luke, A. (1998). Reinventing Literacy in New Times. Journal of adolescent and adult Literacy, 43, 4-7.

Mestry, R., \& Ndhlovu, R. (2014). The implications of the National Norms and Standards for school funding policy on equity in South African public schools. South African Journal of Education, 34(3), 1-11. https://doi.org/10.15700/201409161042

Ministerio de Educación. (2006). Ley de Aseguramiento de la Calidad de la Educación Superior. Santiago, Chile: Ministerio de Educación. https://doi.org/10.1787/9789264180710-8-es

Ministerio de Educación. (2008, November 20). Características del Marco para la Buena Enseñanza. Docentemas. Retrieved August 22, 2018, from https://www.docentemas.cl/docs/MBE2008.pdf

Ministerio de Educación. (2015). Ley de Inclusión Escolar. Santiago, Chile: Ministerio de Educación.

Minsiterio de Educación. (2016). Ley 20.911 Plan de Formación Ciudadana para los establecimientos educacionales reconocidos por el Estado. Santiago, Chile: Ministerio de Educación.

Ministerio de Educación. (2016). Sistema de Desarrollo Profesional Docente. Santiago, Chile: Ministerio de Educación.

Ministerio de Educación. (2018). Propuesta actualización del Marco para la Buena Enseñanza. Santiago, Chile: Ministerio de Educación.

Pereira, E., Da Silva, E., Gonçalves, K., \& Rosa, M. (2018). Formação de profissionais da educação Alguns desafios e demandas da formação inicial de professores na contemporaneidade. Educacao \& Sociedade. 144(39), 721-737. https://doi.org/10.1590/es0101-73302018183273

Schön, D. (1992). La formación de profesionales reflexivos. Hacia un nuevo diseño de la enseñanza y el aprendizaje en las profesiones. Temas de educación (1st ed.). Barcelona, Buenos Aires, México: Paidos. https://doi.org/10.2307/j.ctv5137rb.15

Schwartzman, S. (2015). Education in South America (1st ed.). London, England: Bloomsbury.

Sharma, U., \& Nuttall, A. (2016). The impact of training on pre-service teacher attitudes, concerns, and efficacy towards inclusion. Asia-Pacific Journal of teacher education, 44(2), 142-155. https://doi.org/10.1080/1359866X.2015.1081672

Wakefield, M. (2008). Guía para el Diseño Universal del Aprendizaje. Universidad Autónoma de Madrid. Madrid, España: UAM.

Weare, K. (2011). Mental Healrh and social and emotional Learning: Evidence, principles, tension, balances. Advances in School Mental Health Promotion, 3(1), 5-17. http://doi.org/10.1080/1754730X.2010.9715670 


\section{Appendix}

\begin{tabular}{|c|c|c|c|c|c|}
\hline $\mathbf{N}^{\mathbf{0}}$ & CRITERIA & YES & NO & $\begin{array}{c}\% \\
\text { ideal }\end{array}$ & $\begin{array}{c}\% \\
\text { achieved }\end{array}$ \\
\hline \multicolumn{4}{|c|}{ Domain A: Preparation of the Teaching $(16,6 \%)$} & & \\
\hline A1 & Describe aspects of the discipline he or she manages. & & & 20 & \\
\hline A2 & Describes aspects about knowledge of student experiences. & & & 20 & \\
\hline A3 & Describes aspects of the domain of the didactics of his discipline. & & & 20 & \\
\hline A4 & $\begin{array}{l}\text { He mentions planning in coherence with the curricular framework and } \\
\text { the experiences of the students. }\end{array}$ & & & 20 & \\
\hline A5 & Describes the management of different evaluation techniques. & & & 20 & \\
\hline \multicolumn{4}{|c|}{ Domain B: Creating an enabling environment for learning $(16,6 \%)$} & & \\
\hline B1 & Mentions the importance of climate to generate learning. & & & 25 & \\
\hline $\mathrm{B} 2$ & Expresses the high expectations that must be placed on students. & & & 25 & \\
\hline B3 & $\begin{array}{l}\text { It establishes the importance of the rules to maintain a good } \\
\text { coexistence. }\end{array}$ & & & 25 & \\
\hline B4 & $\begin{array}{l}\text { Mentions the spaces and resources as contributions to improve } \\
\text { learning. }\end{array}$ & & & 25 & \\
\hline \multicolumn{4}{|c|}{ Domain C: Teaching for the learning of all students } & & \\
\hline $\mathrm{C} 1$ & $\begin{array}{l}\text { Mentions the importance of raising, mentioning or following Learning } \\
\text { Objectives (curriculum). }\end{array}$ & & & 16,6 & \\
\hline $\mathrm{C} 2$ & Describes the appropriation or use of learning strategies. & & & 16,6 & \\
\hline $\mathrm{C} 3$ & $\begin{array}{l}\text { It points out aspects of how to download the content so that it is } \\
\text { understandable by the students. }\end{array}$ & & & 16,6 & \\
\hline $\mathrm{C} 4$ & Points out the importance of optimizing time in the classroom. & & & 16,6 & \\
\hline C5 & Mentions the development of thought as part of student learning. & & & 16,6 & \\
\hline
\end{tabular}

\section{Copyrights}

Copyright for this article is retained by the author(s), with first publication rights granted to the journal.

This is an open-access article distributed under the terms and conditions of the Creative Commons Attribution license (http://creativecommons.org/licenses/by/4.0/). 